\title{
Contemporaneous nitrogen fixation and denitrification in intertidal microbial mats: rapid response to runoff events
}

\author{
Samantha B. Joye *, Hans W. Paerl \\ Institute of Marine Sciences, University of North Carolina at Chapel Hill, 3431 Arendell Street, Morehead City, \\ North Carolina 28557, USA
}

\begin{abstract}
We examined the contemporaneous responses of $\mathrm{N}_{2}$ fixation and denitrification to inorganic nitrogen-enriched runoff in 2 intertidal microbial mats in Tomales Bay (California, USA). Prior to runoff, $\mathrm{N}_{2}$ fixation rates averaged $3 \mathrm{mmol} \mathrm{N} \mathrm{m}^{-2} \mathrm{~d}^{-1}$. Denitrification rates were lower, corresponding to 0 to $25 \%$ of $\mathrm{N}_{2}$ fixation rates. After the initiation of runoff, $\mathrm{N}_{2}$ fixation rates decreased approaching zero at both sites. In contrast, denitrification rates increased by an order of magnitude. We developed a simple model to examine the magnitude of $\mathrm{N}$ removal from creek water by mat denitrification before, during and after runoff. Model results show that during peak runoff, $\mathrm{N}$ removal was limited by the residence time of creek water in the intertidal region. As runoff volumes decreased and residence times increased, $\mathrm{N}$ removal became limited by the supply of organic matter. Our results illustrated the rapid metabolic adaptation of microbial mats to altered $N$ fluxes. Changes occurring in the mat $N$ cycling after the initiation of runoff led to 2 fundamental ecological changes: (1) mats became sinks for rather than sources of fixed $\mathrm{N}$ and (2) denitrification became limited by the availability of organic carbon rather than nitrate.
\end{abstract}

\section{INTRODUCTION}

Microbial mats, often dominated by cyanobacteria, are an important productive component of intertidal mudflat and marsh environments (Zedler 1980, Cohen et al. 1984, Cohen \& Rosenberg 1989). Mats often exhibit high rates of $\mathrm{N}_{2}$ fixation (NF) which can provide new sources of fixed nitrogen $(\mathrm{N})$ to intertidal systems (Webb et al. 1975, Wiebe et al. 1975, Paerl et al. 1981. Capone 1983. Stal et al. 1984). In contrast, losses of fixed $\mathrm{N}$ via denitrification (DNF) in microbial mats remain largely unassessed.

Microbial mats experience pronounced variations in oxygen and sulfide distribution due to diel interactions of photosynthesis and respiration (Revsbech \& Ward 1984). The suboxic transition zone between these regions is where DNF could occur. Denitrification may represent a significant $\mathrm{N}$ removal process in mats,

\footnotetext{
- Present address: Tiburon Center for Environmental Studies San Francisco State University, 3150 Paradise Drive, Tiburon, California 94940-0855, USA
}

since they provide a niche well suited to fit the needs of denitrifying populations: specifically, they offer (1) the presence of suboxic regions, (2) potential organic carbon supplied by either in situ autotrophic or heterotrophic means and (3) a nitrate source (either from the water column or via the activity of nitrifying bacteria within the mat)

We have illustrated the occurrence of contemporaneous NF and DNF in microbial mats in Tomales Bay (California, USA) (Joye \& Paerl 1993). On an annual basis, these mats serve as a net source of fixed $\mathrm{N}$ to the intertidal region with DNF rates amounting to $15 \%$ of the NF rates (Joye \& Paerl 1993, Joye unpubl.). However, considerable variation in these processes occurs over shorter time scales (days to months) and we have documented some occasions where the two were in balance. Clearly, by only assessing NF in microbial mats, net inputs to the intertidal system could be significantly overestimated.

Identifying the factors controlling the net balance between NF and DNF is a difficult task. Both NF and DNF have similar requirements, including suboxic 

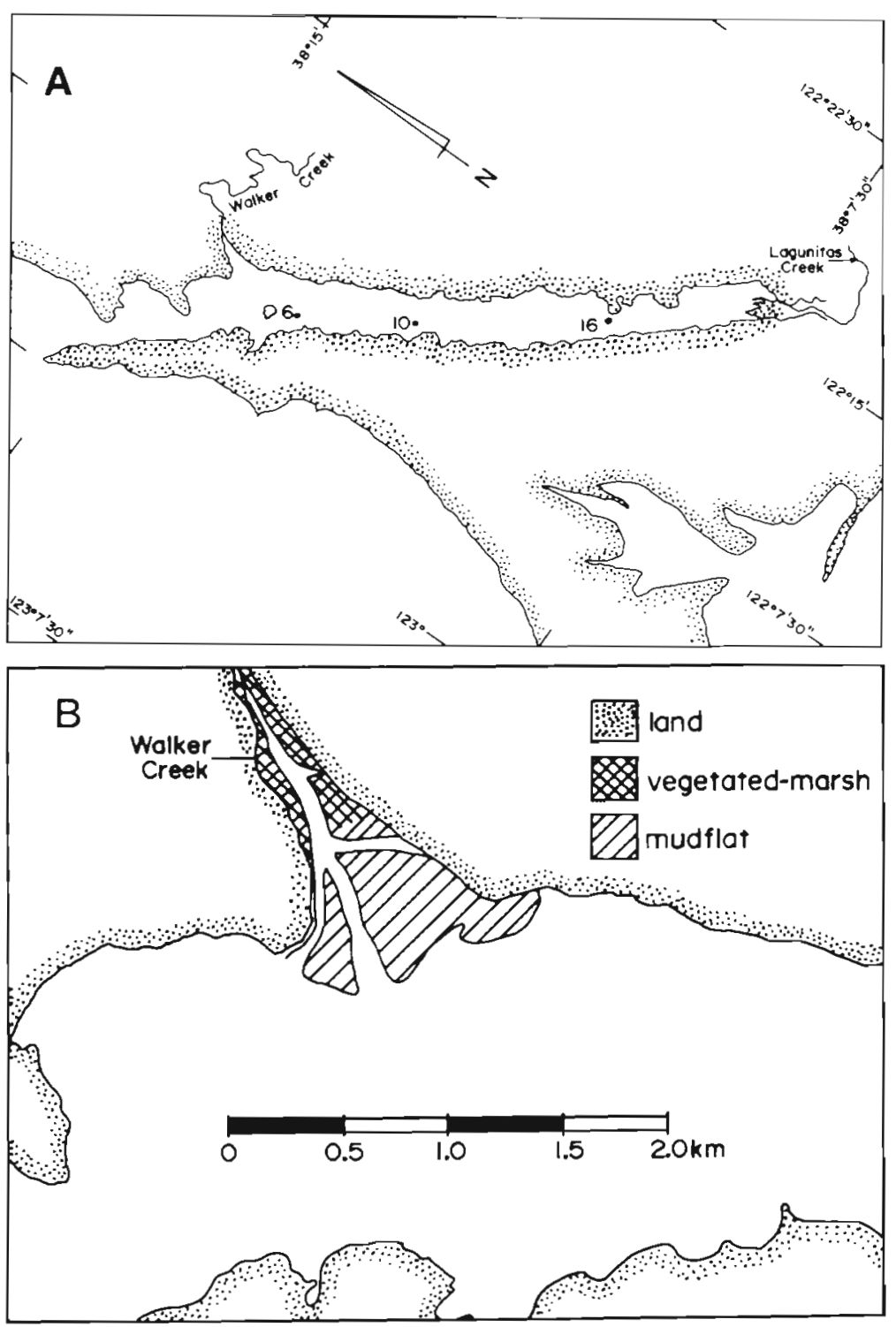

Fig. 1. (A) Tomales Bay (California, USA). (B) Detail of the the intertidal study site at Walker Creek Delta

rainfall and runoff event in over 2 yr took place. Rainfall can be a significant source of naturally- and anthropogenically-generated combined N (Galloway et al. 1984, Zemba et al. 1988, Morris 1991), providing an additional source of nitrogen to intertidal marsh and open estuarine environments (Valiela \& Teal 1979, Correll 1981, Jordan et al. 1988, Paerl 1985, 1992). In addition, runoff serves as a conduit for terrigenous N-loading. As such, the impacts of nitrogen-enriched runoff waters on microbial nitrogen cycling warrant investigation. We examined the response of microbial NF and DNF to this runoff event.

\section{METHODS}

Study site. Tomales Bay is one of 4 U.S. Land Margin Ecosystem Research (L.M.E.R.) Sites. The intertidal zones of the bay are dominated by mudflats which are colonized by microbial mats (Fig. 1). Mudflats are generally covered by 2 to 10 $\mathrm{mm}$ thick mats composed of the filamentous non-heterocystous cyanobacteria Microcoleus sp. and Lyngbya sp. Vegetated Salicornia marshes are rich in mats composed of Oscillatoria sp., Spirulina sp. and an unidentified colonial coccoid cyanobacterium.

Microbial mats were sampled before, during and after the March 1991 storm event (denoted BR (before runoff), DS (during storm), $36 \mathrm{~h}$ ( $36 \mathrm{~h}$ after storm) and $10 \mathrm{~d}$ (10 d after storm) on Figs. 2, 3, \& 4]. All experiments were run under ambient irradiance and temperature conditions (16 to $18^{\circ} \mathrm{C}$ ). Rates of NF and DNF were determined on the same samples incubated

conditions and sufficient supply of organic carbon and energy (Yates 1977, Knowles 1982). The concentration and supply of dissolved inorganic nitrogen (DIN) also exert strong influences on rates of both processes (Yates 1977, Knowles 1982). The addition of $\mathrm{NO}_{3}$ usually stimulates DNE in these mats, whereas DIN addition (either as $\mathrm{NO}_{3}{ }^{-}$or $\mathrm{NH}_{4}{ }^{+}$) results in significant repressions of NF in bioassay experiments (Paerl \& Joye unpubl.). Therefore, the concentration of DIN in creek water should be expected to directly impact both NF and DNF rates.

Northern California experienced a severe drought from 1987 to 1991 (United States Geological Survey unpubl. data). In March 1991, the first substantial under aerobic conditions in the presence of acetylene. Aerobic incubations reflected natural conditions, since mat surfaces were exposed to either air or $\mathrm{O}_{2}$-saturated seawater during various tidal cycles. However, during the storm, mat surfaces were constantly flooded and possibly suboxic.

Nitrogen fixation rates were estimated using the acetylene reduction assay (Hardy et al. 1968). Denitrification rates were estimated by monitoring $\mathrm{N}_{2} \mathrm{O}$ accumulation during incubations, since acetylene also blocks the nitrous oxide reductase enzyme in denitrifying bacteria (Oremland \& Capone 1987). A common problem faced when using the acetylene block assay to measure DNF is that acetylene also blocks 
nitrification, which may provide the nitrate source for denitrifying microorganisms (Oremland \& Capone 1987). If nitrification and DNF are closely coupled, erroneously low rates of DNF would be measured in the presence of acetylene. To account for this possibility, we determined 'potential' DNF rates by amending samples with nitrate ( $1 \mathrm{mM} \mathrm{KNO}_{3}$ ) and organic carbon (1 mM D-glucose). These substrates, in addition to chloramphenicol (1 $\mathrm{g} \mathrm{l}^{-1}$ ), were added to filtered $(\mathrm{GF} / \mathrm{F})$ marsh water, and the solution was sterilized by autoclaving prior to use (Tiedje 1988). Chloramphenicol served to prevent de novo synthesis of denitrifying enzymes in response to $\mathrm{NO}_{3}{ }^{-}$addition.

Small $\left(1 \mathrm{~cm}^{2}\right)$ sections of mat were collected using a cut-off, beveled syringe. The upper $1 \mathrm{~cm}$ was transferred to a $60 \mathrm{ml}$ serum bottle. Twenty $\mathrm{ml}$ of either ambient or amended creek water was added and the bottle was sealed with a serum septum. A $12 \mathrm{ml}$ headspace volume was withdrawn and replaced with $\mathrm{CaC}_{2}$ generated acetylene; bottles were inverted to minimize potential leakage and incubated 1 to $2 \mathrm{~h}$ in a flowing water bath. The following 5 treatments were run in triplicate: (1) blanks (no mat) (2) light-ambient, (3) dark-ambient, (4) light-amended and (5) darkamended. Blanks provided background concentrations for $\mathrm{C}_{2} \mathrm{H}_{4}$ and $\mathrm{N}_{2} \mathrm{O}$ in the water phase and were subtracted from experimental treatments (data not shown).

To terminate incubations, bottles were shaken on a rotary shaker table at $250 \mathrm{rpm}$ for $90 \mathrm{~s}$ to equilibrate $\mathrm{C}_{2} \mathrm{H}_{4}$ and $\mathrm{N}_{2} \mathrm{O}$ between aqueous and gaseous phases. A $15 \mathrm{ml}$ headspace sample was collected by displacement with $1 \mathrm{M} \mathrm{KCl}$ and stored in an evacuated serum bottle for later analysis. Gas analyses were performed using a Shimadzu 14 gas chromatograph equipped with 2 detectors. Ethylene was separated using a $2 \mathrm{~m}$ Poropak T column $\left(80^{\circ} \mathrm{C}\right)$ and analyzed by a flame ionization detector $\left(200^{\circ} \mathrm{C}\right)$. Nitrogen was used as carrier gas. Concentrations were determined by comparison with a standard curve generated with purified $\mathrm{C}_{2} \mathrm{H}_{4}$ (Scott Specialty Gases Inc.). Nitrous oxide was separated on a $2 \mathrm{~m}$ Hayes SepD column $\left(90^{\circ} \mathrm{C}\right.$ ) and analyzed by an electron capture detector $\left(300^{\circ} \mathrm{C}\right) ; 5 \%$ $\mathrm{CH}_{4}$ in $\mathrm{Ar}$ was used as carrier gas. Concentrations were determined by comparison to a standard curve generated with purified $\mathrm{N}_{2} \mathrm{O}$ (Scott Specialty Gases Inc.).

To estimate nitrogen fixation, acetylene reduction rates were transformed to mmol $\mathrm{N}$ fixed $\mathrm{m}^{-2} \mathrm{~d}^{-1}$ using a theoretical conversion factor of $3: 1\left(\mathrm{C}_{2} \mathrm{H}_{2}: \mathrm{N}_{2}\right.$; Hardy et al. 1968). Denitrification rates were calculated as mmol $\mathrm{N} \mathrm{m}^{-2} \mathrm{~d}^{-1}$ to allow direct comparison with $\mathrm{NF}$ rates. Statistical analyses, General Linear Model-Least Significant Difference (GLM-LSD) Procedure, were performed using SAS (SAS Institute 1985).
Creek water samples were collected prior to runoff and 3 and $6 \mathrm{~d}$ after runoff began. These samples were collected as part of the L.M.E.R. routine sampling effort. Water samples were collected directly from the main creek channel (Fig. 1). Samples were filtered $(\mathrm{GF} / \mathrm{F}$ ) into acid-washed, sample rinsed (3 times) polyethylene bottles. Samples were stored frozen for ca 2 wk before analysis. Analyses included total and dissolved nitrogen and phosphorus and dissolved inorganic and organic carbon (DIC \& DOC). DIC concentrations were determined immediately from $\mathrm{pH}$ and alkalinity measurements (Smith et al. 1991). Rainwater was collected using an acid-washed, DIW rinsed funnel and collection bottle placed in an open field near the laboratory. Samples were collected immediately after rain events, filtered and frozen for subsequent analysis. Nitrate was determined using the Cd-shaking technique (Jones 1984). All other analyses (inorganic and organic nutrients) were performed according to the methods given in Smith et al. (1991).

A model for $\mathbf{N}$ removal. We developed a model to examine the potential magnitude of $\mathrm{N}$ removal by mat DNF. We used gauged flow data to estimate delivery volumes and calculated the residence time of a water parcel in the intertidal regions using a simple salt budget. Our calculations assume (1) unidirectional flow from the creek across the marsh and mudflat, (2) a well-mixed water column averaging $0.3 \mathrm{~m}$ over the intertidal area, (3) steady state exchange of water between the intertidal region and the bay, (4) that DNF consumes water column $\mathrm{NO}_{x}\left(\mathrm{NO}_{\mathrm{x}}=\mathrm{NO}_{3}{ }^{+}+\right.$ $\mathrm{NO}_{2}{ }^{-}$) as opposed to $\mathrm{NO}_{x}$ derived from nitrification, and (5) $\mathrm{N}$ removal is additive across the area of the marsh. The residence time of a water parcel in the intertidal region was calculated using the following equation:

$$
T_{\text {res }}=(Z / F)\left[\left(S_{\text {bay }}-S_{\text {in })}\right) / S_{\text {bay }}\right]
$$

where $T_{\text {rcs }}=$ residence time $(\mathrm{h}) ; Z=$ height of the water column in the intertidal region $(\mathrm{m}) ; F=$ flow delivery $\left(\mathrm{m} \mathrm{h}^{-1}\right) ; S_{\text {bay }}=$ open bay salinity; and $S_{1 \mathrm{nt}}=$ intertidal salinity. Flow delivery $\left(F, \mathrm{~m} \mathrm{~h}^{-1}\right)$ was calculated by dividing the gauged flow rate $\left(\mathrm{m}^{3} \mathrm{~h}^{-1}\right)$ by the area of the intertidal region $\left(\mathrm{m}^{2}\right)$. Removal rates were calculated using the following equation:

$$
\% \text { removed }=\left(\text { DNF rate } / N O_{x} \text { delivery }\right) T_{\text {res }}
$$

where \% removed $=$ percentage of $\mathrm{N}$ in available load lost via denitrification (unitless); $D N F$ rate $=\mathrm{mg} \mathrm{N} \mathrm{m}^{-2}$ $\mathrm{h}^{-1} ; \mathrm{N}$ delivery $=\mathrm{mg} \mathrm{N} \mathrm{m}^{-2}$; and $T_{\text {res }}=\mathrm{h}$. The actual amount of $\mathrm{N}$ removed ( $\mathrm{mg} \mathrm{N}$ ) was calculated by multiplying the removal percentage by the $\mathrm{N}$ delivery. It should be noted that total mudflat area is 3 times the total marsh area and that removal percentages and

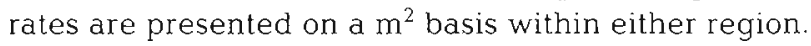


Table 1. Walker Creek nutrient load $\left(\mu \mathrm{mol} \mathrm{l}^{-1}\right.$, except DIC mmol $\left.\mathrm{l}^{-1}\right)$. Creek water: 28 Feb represents pre-runoff conditions, while 3 and 6 Mar represent runoff conditions. Rainwater: first 2 storm events. Errors associated with nutrient analyses are $0.1 \mu$ mol $l^{-1}$ (inorganic nutrients), $0.2 \mu \mathrm{mol} \mathrm{l}^{-1}$ (DON) and $2 \mu \mathrm{mol} \mathrm{l}^{-1}$ (DOC). nd: no data. For location, see Fig. 1

\begin{tabular}{|c|c|c|c|c|c|c|c|c|c|c|}
\hline \multirow[t]{2}{*}{ Date (1991) } & \multicolumn{2}{|c|}{ Carbon } & \multicolumn{5}{|c|}{ Nitrogen } & \multicolumn{3}{|c|}{ Phosphorus } \\
\hline & DIC & DOC & $\mathrm{NO}_{\mathrm{x}}$ & $\mathrm{NH}_{4}$ & TDN & DON & DIN & DIP & TDP & DOP \\
\hline \multicolumn{11}{|l|}{ Creek water } \\
\hline 28 Feb & 2.2 & 1 & 1 & 3 & 27 & 23 & 4 & 1.9 & 2.1 & 0.4 \\
\hline $3 \mathrm{Mar}$ & 1.8 & 0.7 & 143 & 16 & 214 & 55 & 159 & 8.5 & 12.1 & 3.4 \\
\hline $6 \mathrm{Mar}$ & 1.8 & 1.8 & 162 & 7 & 168 & nd & 168 & 3.5 & 3.6 & 0.1 \\
\hline \multicolumn{11}{|l|}{ Rainwater } \\
\hline 27 Feb & nd & 0.1 & 21 & 77 & 101 & 3 & 98 & 0.1 & 0.3 & 0.13 \\
\hline 28 Feb & nd & 0.04 & 13 & 54 & 67 & 0 & 67 & 0.03 & 0.01 & 0.07 \\
\hline
\end{tabular}

\section{RESULTS}

\section{Nutrient concentrations}

Two large rainfall events occurred on 27 and 28 February 1991 resulting in ca $155 \mathrm{~mm}$ of precipitation. Prior to the storm, nitrate concentrations in creek water were $2 \mu \mathrm{M}$. During the initial runoff stages, nitrate levels increased to $166 \mu \mathrm{M}$ but decreased to $17 \mu \mathrm{M} 10 \mathrm{~d}$ later.

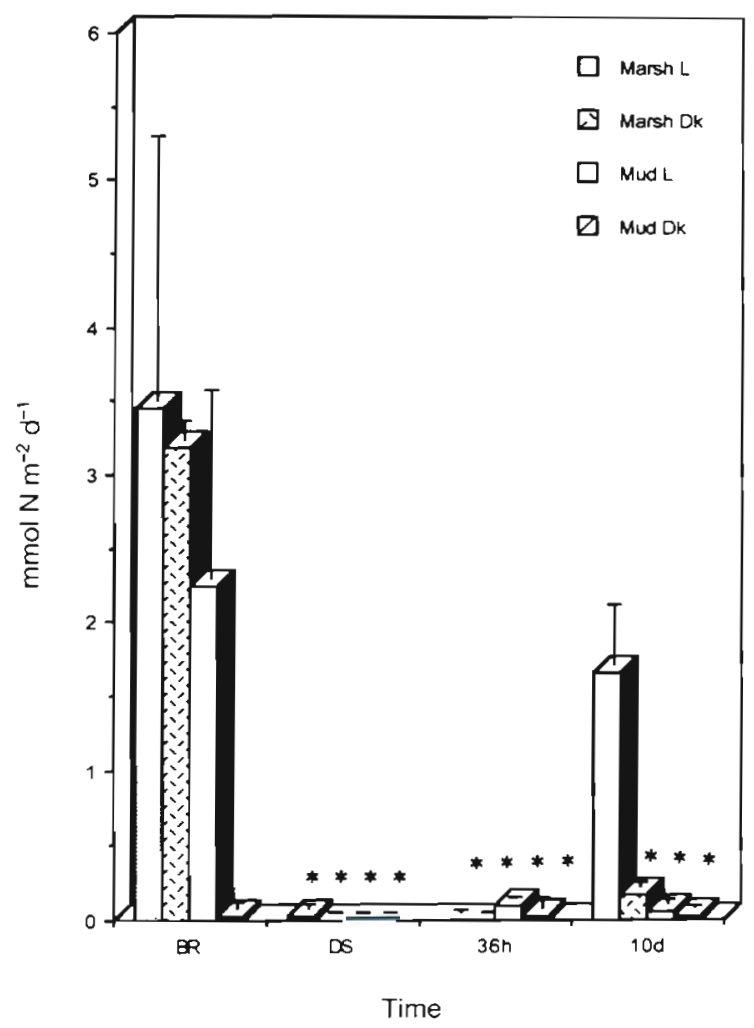

Fig. 2. Rates of nitrogen fixation in microbial mats. BR: before runoff; DS: during storm; $36 \mathrm{~h}$ : post storm $36 \mathrm{~h}$; and 10d: post storm $10 \mathrm{~d}$. Means of triplicate samples + SD. * Rates significantly $(\mathrm{p}<0.05)$ lower than the initial $(B R)$ rate
Before the storm, total dissolved nitrogen (TDN) concentrations in creek water averaged $25 \mu \mathrm{M}$ of which organic nitrogen was the major component (DON, $86 \%$; Table 1). Salinity at the site was depressed within 24 h by runoff (reduced from 30.5 to $18 \mathrm{ppt}$ ) and the TDN pool switched from domination by DON to dissolved inorganic nitrogen (DIN, $74 \%$; Table 1), nearly reversing pre-runoff conditions. Rainwater TDN concentration was $98 \mu \mathrm{M}$ and also dominated by inorganic forms (Table 1). Nitrate concentrations in the initial rainfall event (first $2 \mathrm{~h}$ ) was much higher (> 200 $\mu \mathrm{M})$ than the total integrated concentration shown in Table 1 (data not shown). Levels of DIN remained high in runoff waters for at least $3 \mathrm{~d}$ (Table 1 ).

\section{Nitrogen fixation rates}

$\mathrm{N}_{2}$ fixation rates were highest in marsh Salicornia mats (hereafter marsh) prior to the storm (Fig. 2, BR). Rates in mudflat mats (hereafter mudflat) were comparable to light rates in the marsh (Fig. 2, BR). After runoff began, NF rates decreased significantly at both sites ( $\mathrm{p}<0.05$; Fig. 2, DS). Rates remained depressed for at least $36 \mathrm{~h}$ at both sites but increased $10 \mathrm{~d}$ later at the marsh site (Fig. 2, 36h, 10d). Rates remained low at the mudflat site during this time (Fig. 2, 10d).

\section{Denitrification rates}

Prior to the storm, ambient rates were lower than amended rates (Fig. 3, BR). Shortly after runoff began, rates increased significantly $(p<0.05)$ with ambient exceeding amended rates (Fig. 3, DS). Thirty-six hours after the storm ended, ambient denitrification rates remained significantly higher than pre-storm rates $(p<0.05)$; no further rate increases were observed. However, potential rates continued to increase, eventually surpassing ambient rates (Fig. 3, 36h). Ten days 


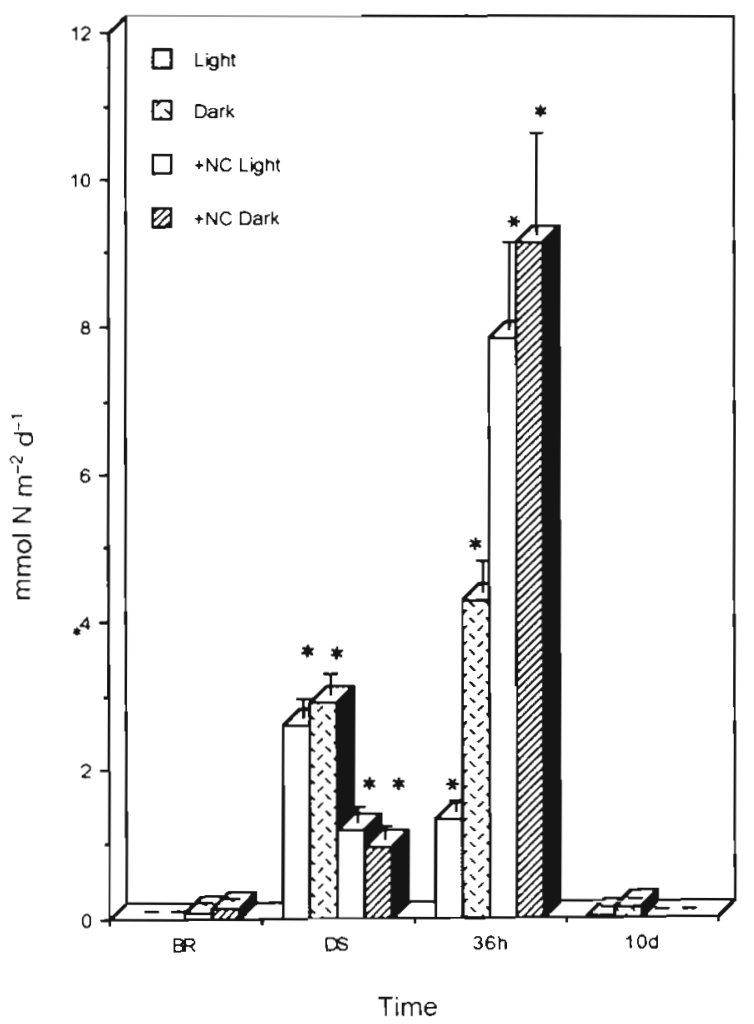

Fig. 3. Denitrification rates in marsh mats. Light and dark treatments with ambient or amended $1+\mathrm{NC}=+\mathrm{NO}_{3}{ }^{-}$and glucose) creekwater; for details, see text. Means of triplicate samples $+\mathrm{SD}$. Rates significantly $(\mathrm{p}<0.05)$ higher than the initial (BR) rate

after the storm, ambient rates approached pre-runoff values (Fig. 3).

At the mudflat site, a similar pattern was observed but maximum rates were lower. Prior to the storm, potential rates were 3 times higher than marsh rates (Fig. $4, \mathrm{BR})$. During the storm, ambient rates increased significantly ( $p<0.05$; Fig. 4 , DS). Rates were statistically similar $36 \mathrm{~h}$ later (Fig. 4, 36h) and approached pre-runoff values $10 \mathrm{~d}$ later (Fig. 4, 10d).

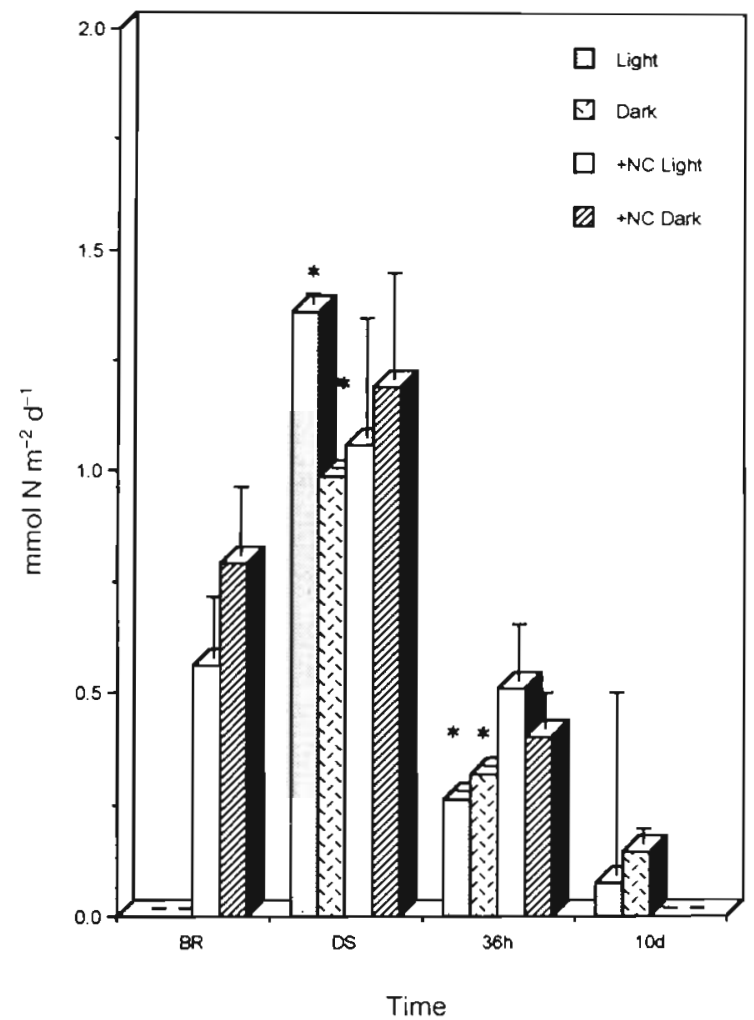

Fig. 4. Denitrification in mudflat mats. Treatments as in Fig. 3. Means of triplicate samples + SD. - Rates significantly $(p<0.05)$ higher than the initial $(B R)$ rate

\section{Model results}

Potential $\mathrm{N}$ removal ( $\mathrm{mg} \mathrm{N} \mathrm{m}^{-2}$ ) before runoff was similar to ambient removal $10 \mathrm{~d}$ after the storm (Table 2). After runoff began, ambient $N$ removal increased at both sites and appeared to be closely related to the residence time $\left(T_{\text {res }}\right)$ of the water parcel within the intertidal region. During the storm (high flow volumes), $N$ removal was not statistically different between ambient and amended treatments (data not shown, see Figs. 3 \& 4). Removal appeared to be limited by the $T_{\text {res }}$ of

Table 2. Nitrate removal by microbial mat denitrification before, during and after the initiation of runoff. $T_{\text {res }}$ : residence time of a water parcel within the intertidal region (for calculation see 'methods'); percent denitrified: percent of $N$ available lost via DNF; $\mathrm{N}$ removed: amount of $\mathrm{N}$ available removed by denitrification

\begin{tabular}{|c|c|c|c|c|c|c|c|}
\hline \multirow[t]{2}{*}{ Time } & \multicolumn{3}{|c|}{ March } & \multicolumn{3}{|c|}{ Muflat } & \multirow{2}{*}{$\begin{array}{l}\text { Total } \\
\text { removed } \\
\text { (mg) } \mathrm{N}\end{array}$} \\
\hline & $\begin{array}{l}T_{\text {res }} \\
(\mathrm{h})\end{array}$ & $\begin{array}{c}\text { Percent } \\
\text { denitrified }\end{array}$ & $\begin{array}{c}N \text { removed } \\
\text { (mg) }\end{array}$ & $\begin{array}{l}T_{\text {res }} \\
\text { (h) }\end{array}$ & $\begin{array}{c}\text { Percent } \\
\text { denitrified }\end{array}$ & $\begin{array}{l}\text { N removed } \\
\text { (mg) }\end{array}$ & \\
\hline Before runoff & 7 & $\gg 100$ & 0.6 & 10 & $>>100$ & 1.9 & 2.6 \\
\hline During storm & 1 & 3 & 1.4 & 1 & 5 & 2.2 & 3.6 \\
\hline \multicolumn{8}{|l|}{$36 \mathrm{~h}$ after storm } \\
\hline Ambient & 10 & 37 & 17 & 14 & 17 & 5.4 & 22.4 \\
\hline Potential & 10 & $>>100$ & 54 & 14 & $\gg 100$ & 50 & 104 \\
\hline $10 \mathrm{~d}$ after storm & 6 & 20 & 1 & 8 & 42 & 1.8 & 2.8 \\
\hline
\end{tabular}


the water parcel in the intertidal region. After the storm (36 h), flow volumes decreased and $T_{\text {res }}$ increased. At this time, $N$ removal in ambient and amended treatments were significantly different at the marsh site suggesting that the availability of organic carbon limited $\mathrm{N}$ removal in ambient treatments (Table 2). In contrast, at the mudflat site, ambient and potential removal rates were similar.

\section{DISCUSSION}

\section{Response to $\mathrm{N}$-enriched runoff}

A common feature of microbial mat communities is their ability to rapidly acclimate to changing environmental conditions. The onset of runoff (high flow) conditions led to profound physical/chemical changes in the marsh/mudflat environment. Possible consequences of high flow conditions include alterations of sediment redox conditions (due to continual flooding of sediments), reductions in salinity, and sediment and nutrient (both organic and inorganic) loading. Since our emphasis was placed on examining changes in nutrient concentrations, the discussion is focused on effects of inorganic nutrient loading on microbial $\mathrm{N}$ cycling.

Both creek water DIN concentration and the N:P ratio changed following the initiation of runoff (Table 1). Both of these parameters affect NF rates (Yates 1977). During the runoff period, concentrations of DIN increased by 2 orders of magnitude. The N:P ratio indicated N-limited growth conditions before runoff; however, after runoff began, it suggested an excess of $N$ ( P limitation). Runoff waters were enriched in DIN compared to both DOC and DIP (Table 1). Rates of NF were rapidly and significantly $(p<0.05)$ reduced at both sites, as a result of these factors. Only when DIN concentrations and the $\mathrm{N}: \mathrm{P}$ ratio decreased $\left(\left[\mathrm{NO}_{3}{ }^{-}\right]=\right.$ $17 \mu \mathrm{M}$ and $\mathrm{N}: \mathrm{P}=6, \mathrm{ca} 8 \mathrm{~d}$ later) did $\mathrm{NF}$ rates begin to approach pre-runoff levels.

Rates and patterns of DNF differed between the 2 sites and appeared to depend on factors in addition to ambient $\mathrm{NO}_{x}$ concentrations. Prior to runoff, denitrification was limited by the availability of $\mathrm{NO}_{3}{ }^{-}$; the addition of glucose did not stimulate rates (data not shown). During the initiation of runoff, denitrification rates increased as denitrifiers were exposed to increasing $\left[\mathrm{NO}_{\mathrm{x}}\right]$. At the marsh site, despite continued elevation of $\left[\mathrm{NO}_{x}\right]$, ambient rates leveled off while potential rates continued to increase. This suggests that supply rate of another substrate, most likely organic carbon, controlled the activity of the denitrifying population. If potential rates had been realized, the amount of $\mathrm{N}$ removed by the intertidal DNF during at this time would have increased 3 -fold.
In addition to potential organic carbon limitation of DNF, differential photosynthetic oxygen production may have influenced DNF, by affecting a switch from $\mathrm{NO}_{x}$ to $\mathrm{O}_{2}$ respiration among denitrifiers. Most denitrifiers are facultative, switching to $\mathrm{O}_{2}$ respiration when $\mathrm{O}_{2}$ concentrations exceed $10 \mu \mathrm{M}$ (Tiedje 1988). Additionally, denitrifiers may have been outcompeted for $\mathrm{NO}_{x}$ by assimilatory processes among diverse benthic microflora. Interactions between phototrophs and denitrifiers for $\mathrm{NO}_{x}$, whether indirect (photosynthetically produced $\mathrm{O}_{2}$ inhibiting denitrification) or direct (competition for $\mathrm{NO}_{\mathrm{x}}$ ), resulted in lowered DNF rates.

\section{Ecological ramifications}

The ecological role of mat communities in intertidal $\mathrm{N}$-dynamics changed in response to runoff: namely, mats became sinks for rather than sources of fixed $N$ during the runoff event. Denitrification in microbial mats is dependent on several environmental factors in addition to the previously mentioned 'substrate requirements'. During and after the storm, 2 important changes occurred that, together, could have led to the observed enhancement of DNF rates. First, the dominant form of TDN changed from organic to inorganic $\left(\mathrm{NO}_{\mathrm{x}}\right)$, a form directly accessible to denitrifying organisms (as opposed to DON which would have to be ammonified and nitrified prior to DNF). Second, turbid runoff waters may have limited light penetration which reduced primary production, allowing denitrifiers to maximize $\mathrm{NO}_{x}$ uptake free of competition. Taking these factors into consideration, how much $\mathrm{N}$ could be removed from creek water via microbial DNF? Did Nremoval increase after runoff began? We were able to address these questions by modeling $\mathrm{N}$-removal by mat communities.

The potential for $\mathrm{N}$ removal by the microbial mat community was a function of several factors, most importantly the residence time $\left(T_{\text {res }}\right)$ of the water parcel in the intertidal region. During periods of low flow (before runoff), $T_{\text {res }}$ was on the order of a tidal cycle and removal efficiencies were high. Over this time scale, DNF could have removed all of the $\mathrm{NO}_{\mathrm{x}}$ from a given water parcel. In fact, DNF could have removed more $\mathrm{NO}_{\mathrm{x}}$ than that available in creek water, suggesting the possibility of an additional $\mathrm{NO}_{\mathrm{x}}$ source (e.g. in situ nitrification). During the storm, flow volumes increased and $T_{\text {res }}$ was shortened $(<1 \mathrm{~h}$ ). Denitrification rates increased by an order of magnitude in response to $\mathrm{N}$-enriched runoff. However, $\mathrm{N}$ removal rates increased by only a factor of 2 . The disparity between increased DNF rates and $N$ removal can be ascribed to the short $T_{\text {res }}$ calculated for this period. Thus, the high flow phase of runoff-associated DNF activity can be 
thought of as 'contact-limited': $\mathrm{N}$ removal by the local mat community was limited by the amount of time the mat was in contact with runoff waters. On a larger scale, there may have been additional communities which process this material.

After the storm passed, lower flow volumes resulted in longer $T_{\text {res }}$ and ultimately to increased $\mathrm{N}$ removal. At the $36 \mathrm{~h}$ sampling, removal rates at the marsh and mudflat sites were significantly different. Removal at the marsh site increased by an order of magnitude even though the DNF rates increased by only $25 \%$ (Fig. 3). Again, the importance of $T_{\text {res }}$ in determining the amount of $\mathrm{N}$ removed is illustrated. At this time, mat organisms were no longer 'contact-limited'. The marsh community apparently became limited by another substrate, most likely organic carbon. Removal of $\mathrm{NO}_{x}$ in glucose $+\mathrm{NO}_{3}{ }^{-}$amended treatments was 3 times the removal in $\mathrm{NO}_{3}{ }^{-}$-amended treatments. This underscores the second fundamental runoff-induced change in microbial mat $\mathrm{N}$ dynamics: a transition from $\mathrm{NO}_{x}$ to organic carbon limitation of DNF. This phenomenon was noted only in marsh mats. Removal of $\mathrm{N}$ in mudflat mats increased (due to longer $T_{\text {res }}$ ) despite lower mean DNF rates. We can provide some speculation as to the cause of this difference between sites. The mudflat site received a substantial amount lat least $5 \mathrm{~mm}$ ) of sediment deposition during the period of high flow and appeared to be anaerobic (black coloration and sulfidic smell). Reduced conditions may have limited the expansion of the denitrifying community which resulted in no further rate increase after the DS sampling.

The majority of DNF activity before runoff, during the initial stages of runoff and after runoff $(10 \mathrm{~d})$ occurred in the mudflat region. Only at the $36 \mathrm{~h}$ sampling did the marsh region dominate $\mathrm{N}$ removal. At this time, under organic carbon replete conditions, mats (summed over the intertidal region) could have removed more than $100 \%$ of $\mathrm{NO}_{\mathrm{x}}$ in runoff waters (104 mg $\mathrm{N} \mathrm{m}^{-2}$ ) whereas $50 \%\left(22.4 \mathrm{mg} \mathrm{N} \mathrm{m}^{-2}\right.$ ) was removed under ambient conditions.

Enhanced $\mathrm{NO}_{x}$ removal due to microbial DNF was short-lived. Once DIN concentrations decreased, NF rates increased and mats became sources of fixed $\mathrm{N}$ again. Denitrification rates were comparable to prerunoff values, amounting to $10 \%$ of NF rates. The transition from source to sink of fixed $\mathrm{N}$ occurred rapidly and was sustained for ca $1 \mathrm{wk}$. During this time however, a substantial amount of $\mathrm{N}$ was removed via microbial DNF. Assuming a turnover rate of $0.5 \mathrm{~d}^{-1}$, mats could have removed $44 \mathrm{mg} \mathrm{N} \mathrm{m}^{-2} \mathrm{~d}^{-1}$, an amount comparable to $\mathrm{N}$ input prior to the storm ( $49 \mathrm{mg} \mathrm{N} \mathrm{m}^{-2} \mathrm{~d}^{-1}$ ). The amount of $\mathrm{N}$ removed by DNF was limited by 2 factors: (1) the $T_{\text {res }}$ during periods of high flow (short $T_{\text {res }}$ ), and (2) substrate (organic carbon) limitation dur- ing periods of longer $T_{\text {res }}$. Flow volumes continued to decrease during the next week and $T_{\text {res }}$ would have gradually increased towards initial (before runoff) values. Therefore, hydrological limitation of DNF was likely to occur only during the $2 \mathrm{~d}$ period of peak flow. It appears that, overall, the availability of organic carbon determined the efficiency of $\mathrm{N}$-removal by microbial mat communities. Such 'carbon-controlled nitrogen cycling' has been inferred based on stoichiometric nutrient models (Smith \& Hollibaugh 1989), but to our knowledge this is the first documentation of its occurrence in situ.

Acknowledgements. This work was performed as part of the Tomales Bay L.M.E.R. program. We thank S. Vink for field assistance and S. V. Smith for providing nutrient and gauged flow data. Critical reviews by C. Currin, M. Braun and 2 anonymous reviewers substantially improved this manuscript. $\mathrm{S} . \mathrm{V}$. Smith assisted in development of the $\mathrm{N}$ removal model This work was supported by NSF grants OCE 89-14833, OCE 90-12496, and OCE 91-15706.

\section{LITERATURE CITED}

Cohen, Y., Castenholtz, R. W., Halvorson, H. O. (eds.) (1984). Microbial mats: stromatolites. Am. Soc. Microbiol., Washington, DC

Cohen, Y, Rosenberg, H. (eds.) (1989). Microbial mats: physiologicial ecology of benthic microbial communities. Amer. Soc. Microbiol., Washington, DC

Capone, D. G. (1983). Benthic $\mathrm{N}_{2}$ fixation. In: Carpenter, E. J., Capone, D. G. (eds.) Nitrogen in the marine environment. Academic Press, New York, p. 105-137

Correll, D. L. (1981). Nutrient mass balances for the watershed, headwaters, intertidal zone and basin of the Rhode River estuary. Limnol. Oceanogr. 26: 1142-1149

Galloway, J. N., Charlson, R. J., Andreae, M. O., Rodhe, H. (eds.) (1984). The biogeochemical cycling of sulfur and nitrogen in the remote atmosphere. NATO Advanced Research Workshop. D. Reidel Publ. Co.

Hardy, R. W. F., Holsten, R. D., Jackson, E. K., Burns (1968). The acetylene-ethylene assay for nitrogen fixation: laboratory and field evaluation. Plant Physiol. 43: $1165-1207$

Jones, $M$. (1984). Nitrate reduction by shaking with cadmium: alternative to cadmium columns. Water Res. 18: 643-646

Jordan, T E., Correll, D. L., Whigham, D. F. (1988). Nutrient flux in the Rhode River: tidal exchange of nutrients by brackish marshes. Estuar. coast. Shelf Sci. 17: 651-657

Joye, S. B., Paerl, H. W. (1993). Nitrogen fixation and denitrification in the intertidal and subtidal environments of Tomales Bay, California. In: Oremland, R. S. (ed.) The biogeochemistry of global change: radiative trace gases. Blackwell Scientific, New York, p. 633-653

Knowles, R. (1982). Denitrification. Microbiol. Rev. 46(1): $43-70$

Meybeck, M. (1982). Carbon, nitrogen and phosphorus transport by world rivers. Am. J. Sci. 282: 401-450

Morris, J. T (1991). Effects of nitrogen loading on wetland ecosystems with particular reference to atmospheric deposition. A. Rev. ecol. Syst. 22: 257-279

Oremland, R. S., Capone, D. G. (1987). Use of specific inhibi- 
tors in microbial ecology and biogeochemical studies. In: Marshall, K. C. (ed.) Advances in microbial ecology, Vol. 10. Plenum Press, New York, p. 285-383

Paerl, H. W. (1985). Enhancement of marine primary productivity by nitrogen-enriched acid rain. Nature 316: 747-749

Paerl, H. W. (1992). Interaction of nitrogen and carbon cycles in the marine environment. In: Ford, T. (ed.) Aquatic microbiology: an ecological approach. Blackwell Scientific, Oxford (in press)

Paerl, H. W., Webb, K. L., Baker, J., Wiebe, W. J. (1981). Nitrogen fixation in natural waters. In: Broughton, W. J. (ed.) Nitrogen fixation, Vol. 1 Ecology. Clarendon Press, Oxford, p. 193-240

Revsbech, N. P., Ward, D. M. (1984). Microprofiles of dissolved substances and photosynthesis in microbial mats measured with microelectrodes. In: Cohen, Y., Castenholtz, R. W., Halvorson, H. O. (eds.) Microbial mats: stromatolites. Am. Soc. Microbiol., Washington, DC, p. $171-188$

SAS Institute, Inc. (1985). SAS users guide: statistics, Version 5 edn. SAS Institute Inc., Cary, NC

Smith, S. V., Hollibaugh, J. T. (1989). Carbon-controlled nitrogen cycling in a marine 'macrocosm': an ecosystem-scale model for managing cultural eutrophication. Mar. Ecol. Prog. Ser. 52: 103-109

Smith, S. V., Hollibaugh, J. T., Dollar, S. J., Vink, S. M. (1991). Tomales Bay metabolism: C-N-P stoichiometry and

This article was presented by $G$. W. Thayer, Beaufort, N. Carolina, USA ecosystem heterotrophy at the land-sea interface. Estuar. coast. Shelf Sci. 33: 223-257

Stal, L. J., Grossberger, S., Krumbein, W. E. (1984). Nitrogen fixation associated with the cyanobacterial mat of a marine laminated microbial ecosystem. Mar. Biol. 82: $217-224$

Tiedje, J. M. (1988). Ecology of denitrification and dissimilatory nitrate reduction ta ammonium. In: Zehnder, A. J. B. (ed.) Biology of anaerobic microorganisms. John Wiley \& Sons, New York, p. 179-243

Valiela, I., Teal, J. M. (1979). The nitrogen budget of a salt marsh ecosystem. Nature 280:652-656

Webb, K. L., Dupaul, W. E., Wiebe, W. J., Scottile, W., Johannes, R. E. (1975). Erewetak (Eniwetok) Atoll: aspects of the nitrogen cycle on a coral reef. Limnol. Oceanogr. 20: $198-210$

Wiebe, W. J., Johannes, R. E., Webb, K. L. (1975). Nitrogen fixation in a coral reef community. Science 188: 257-259

Yates, M. G. (1977). Physiological aspects of nitrogen fixation. In: Newton, W., Postgate, J. R., Rodrigues-Barrueco, C. (eds.) Recent developments in nitrogen fixation. Academic Press, London, p. 219-270

Zedler, J. B. (1980). Algal mat productivity: comparisons in a salt marsh. Estuaries 3: 122-132

Zemba, S. G., Golomb, D., Fay, J. A. (1988). Wet sulfate and nitrate deposition patterns in eastern North America. Atmosph. Environ. 22: 2751-2761

Manuscript first received: April 20, 1992

Revised version accepted: December 29, 1992 